\title{
Social, economic and academic leadership: some introductory remarks
}

\author{
Wadim Strielkowski \\ Prague Institute for Qualification Enhancement \\ Trnkovo náměstí 1112/2, 152 00, Prague \\ Czech Republic \\ e-mail: strielkowski@prizk.cz
}

\begin{abstract}
Our rapidly changing and deteriorating modern world is marked by globalization and digitalization that are making it both smaller and more far apart. In addition, it is marked by the growing inclinations to sustainable economic growth that arises in the face of such threats as global warming and global climate change. All these creates a need for concepts and ideas that would enhance a steady and secure development. The concept of leadership in all its spheres and realms that includes social and educational practices, academic policies, or business environment from the point of view of academic experts, researchers and entrepreneurs becomes one of the key concepts of this path.

This short paper provides an opening word and an introduction to the Proceedings from the $2^{\text {nd }}$ International Conference on Social, Economic, and Academic Leadership (ICSEAL 2018) that was held Prague on the $18^{\text {th }}$ and $19^{\text {th }}$ of June 2018 by the Prague Institute for Qualification Enhancement.
\end{abstract}

\section{Introduction}

If one had just one sentence to describe and characterize the proceedings of the $2^{\text {nd }}$ International Conference on Social, Economic, and Academic Leadership (ICSEAL 2018), the best description would be to say that they draw from the novel and up-to-date research conducted by the researchers and stakeholders from various fields of business, economics, education, social sciences, psychology and behavioural sciences, pedagogy and linguistics, as well as policy-makers responsible for the creation and maintenance of the sets of rules for the future sustainable development of business and education. The proceedings originated from the materials of the international conference that took place in Prague, Czech Republic, on the $18^{\text {th }}$ and $19^{\text {th }}$ of June 2018 (PRIZK 2018).

The ICSEAL 2018 conference was envisaged as the second one in a series of successive events following the successful $1^{\text {st }}$ International Conference "Social, economic, and academic leadership for the future sustainable development of business and education" held in Prague during from $12^{\text {th }}$ to $15^{\text {th }}$ of September 2017. The 2017 Conference resulted in the publication of the Springer Proceedings in Business and Economics book of proceedings that was released in 2018 (Strielkowski and Chigisheva 2018).

Through collecting, carefully cataloguing and scrutinizing opinions of the experts both from theory and from practice with an impact on economic analysis and economic theory, our conference proceedings provide a toolbox for the creation, assessment and promotion of all possible aspects and angles of leadership aimed at the future sustainable economic development of business and education. The outcomes of the conference reflect the challenges to the global world order of the $21^{\text {st }}$ century as we know it (see e.g. Gilpin 2018). This is of a special importance in today's digitalized and globalized world where information can spread in a fraction of a second, sometimes becoming a helper and sometimes representing a serious threat to the democratic and human values (Crevani 2018).

\section{Scope and structure}

The $2^{\text {nd }}$ International Conference on Social, Economic, and Academic Leadership organized by the Prague Institute for Qualification Enhancement offered a wide range of keynote speeches, oral presentations and poster presentations, as well as roundtables, and workshops.

After a careful selection of contributions and placing them under rigorous peer-review, over 50 papers were selected to be published and put online. The papers in question tackle various fields of social sciences and humanities but have one unifying topic - namely leadership in its social, economic and academic realms.

In order to cluster the papers by the similar thematic spheres to make them fit better together, all of them were placed into one of the five following topics listed below. Thence, the structure of the proceedings can be described as follows:

- $\quad$ Leadership as a social, psychological, and (pop)cultural phenomenon 
- Leadership in social practice

- Leadership in business and economics

- Leadership in higher education: commercialization of R\&D

- Leadership, energy, and sustainable growth

- Leadership, sustainability, and global security

It has to be mentioned that the conference organizers managed to achieve a truly international mixture of contributors from such countries as Armenia, Czech Republic, Georgia, Lithuania, Poland, Russian Federation, and Ukraine. Many papers are interdisciplinary and co-authored by the teams of researchers from various countries that increases the multidisciplinary and multi-national nature of the presented research.

\section{Some concluding remarks}

Overall, it becomes obvious that the proceedings from the $2^{\text {nd }}$ International Conference on Social, Economic, and Academic Leadership represent an interesting blend of research papers from various fields and topics unified by the idea of leadership.

Leadership becomes one of the key topics in the $21^{\text {st }}$ century as we have to concentrate both on leaders as individuals and the interaction of leaders or teams of leaders acting together, in unison or with opposing interests and ideas. The complexity of this process makes the study of leadership from various angles to be necessity rather than a peculiar exercise.

Thence, our proceedings might therefore be of some special interest for the policy-makers, stakeholders, researches and academics who are interested in various aspects of leadership and would like to find out more both about theory behind the ideas and concepts of leadership, and about case studies of leaders and leadership issues from all around the world.

\section{References}

Crevani L (2018) Is there leadership in a fluid world? Exploring the ongoing production of direction in organizing. Leadership 14(1):83-109. doi: 10.1177/1742715015616667

Gilpin R, The challenge of global capitalism: The world economy in the 21 st century, 9783rd edn. (Princeton University Press, 2018), 408 p.

McCarthy JD (2017) How Organizations Develop Activists: Civic Associations and Leadership in the 21st Century. Social Forces 95(4):e2-e2. doi: 10.1093/sf/sov125

PRIZK (2018) Website of the $2^{\text {nd }}$ International Conference on Social, economic, and academic leadership (ICSEAL 2018). https://www.prizk.cz/en/leadership-conference-2018/ Accessed 10 Sep 2018

Strielkowski W, Chigisheva O (eds.), Leadership for the Future Sustainable Development of Business and Education, $1^{\text {st }}$ edn. (Springer Proceedings in Business and Economics. Springer, Cham, 2018), 672 p., doi: 10.1007/978-3-319-74216-8 